\title{
Aplikasi Ensiklopedia Pakaian Adat Dunia Berbasis Android
}

\author{
Budi Permana $^{1}$, Eka Wahyu Hidayat ${ }^{2}$, Alam Rahmatulloh ${ }^{3 *}$ \\ 1,2,3 Jurusan Teknik Informatika, Fakultas Teknik, Universitas Siliwangi, Tasikmalaya \\ ${ }^{1,2,3} \mathrm{Jln}$. Siliwangi, Kota Tasikmalaya, 46115, Indonesia \\ email: 'budipermana@gmail.com, ${ }^{2}$ ekawahyu@unsil.ac.id, ${ }^{3}$ alam@unsil.ac.id
}

Received: 15 Februari 2018; Revised: 9 Mei 2018; Accepted: 13 Mei 2018

Copyright $@ 2018$ Politeknik Harapan Bersama Tegal. All rights reserved

\begin{abstract}
The rapid development of technology and with the disruptive technology make multimedia developers continuously innovate in making specific information products. Internet as a source of information can be used as a reference to seek various information such as information about custom clothing from around the world. In addition to sources from the internet, many available information about custom clothing for example in print. The use of both media is found a variety of problems that Internet users must search for one by one information and readers should find information custom clothing one by one following details and explanations. The problem is solved by creating a digital encyclopedia about custom clothing in digital form based on multimedia technology using mobile application with Android operating system. The method for multimedia software engineering uses Luther method with its stages of concept, design, collecting material, assembly, testing, and distribution. The end result of this research in the form of multimedia products encyclopedia custom clothing in the form of android applications. Product test results have been passed using functionality testing and all functions can run well and in accordance with the concept. From the results of the survey on beta test results obtained $83 \%$ which states that the application is feasible to use.
\end{abstract}

Abstrak - Perkembangan teknologi yang cepat dan dengan adanya disruptive technology membuat developer bidang multimedia melakukan inovasi dalam membuat produk informasi yang spesifik. Internet sebagai sumber informasi dapat dijadikan rujukan mencari berbagai informasi misalnya informasi mengenai pakaian adat dari seluruh dunia. Selain sumber dari internet, banyak tersedia media informasi mengenai pakaian adat misalnya dalam bentuk cetak. Penggunaan kedua media tersebut ditemukan berbagai masalah yaitu pengguna internet harus mencari satu persatu informasi yang diinginkan dan pembaca harus mencari informasi pakaian adat satu persatu berikut rincian dan penjelasannya. Permasalahan tersebut diatasi dengan membuat ensiklopedia digital mengenai pakaian adat dalam bentuk digital berbasis multimedia memanfaatkan teknologi mobile application dengan sistem operasi Android. Metode untuk rekayasa perangkat lunak multimedia menggunakan metode Luther dengan tahapannya yaitu concept, design, material collecting, assembly, testing, dan distribution. Hasil akhir dari penelitian ini berupa produk multimedia ensiklopedia pakaian adat dalam bentuk aplikasi android. Hasil pengujian produk telah dilalui menggunakan pengujian fungsionalitas dan semua fungsi dapat berjalan dengan baik dan

*) Corresponding author: Alam Rahmatulloh

Email: alam@unsil.ac.id sesuai dengan konsep. Dari hasil survey pada pengujian beta didapat hasil $83 \%$ yang menyatakan bahwa aplikasi layak digunakan.

Kata Kunci - Adat, Android, Dunia, Ensiklopedia, Pakaian

\section{PENDAHULUAN}

Laju perkembangan dunia informasi kini semakin pesat, ini membuktikan bahwa kebutuhan akan informasi sangat tinggi. Buku adalah salah satu media manusia untuk menambah pengetahuan serta informasi. Salah satu bentuk buku yang sangat lengkap menampilkan informasi-informasi yang dibutuhkan seperti buku Ensiklopedia, saat ini di Dunia banyak bermunculan buku Ensiklopedia, seperti Ensiklopedia Britannica, Ensiklopedia Islam Indonesia, dan sebagainya.

Setiap daerah memiliki beragam adat dan budaya, salah satunya yang menjadi ciri khas masing-masing daerah adalah pakaian adat. Indonesia sendiri memiliki beragam pakaian adat dari setiap daerah, belum lagi dari negara lain. Sampai saat ini belum ada media ensiklopedia digital yang dapat menampung jumlah pakaian adat dunia. Sehingga diperlukan semacam buku ensiklopedia namun dengan penerapan teknologi informasi yang penyajiannya dalam bentuk digital. Pada era digital ini sedang trend penggunaan aplikasi mobile dengan sistem operasi Android [1] begitu juga menurut hasil penelitian [2] agar konten lebih menarik perlu disajikan dalam bentuk multimedia, karena produk multimedia yang disajikan pada aplikasi android mampu menjadi media pembelajaran yang interaktif.

Penelitian [3] hanya menjelaskan pengenalan budaya dari 33 provinsi di Indonesia, kemudian penelitian [4] menjelaskan pakaian adat namun sebatas nusantara dan hanya memuat pakaian adat tradisional Indonesia [5]. Begitu juga pada penelitian [6] yang hanya menyajikan pengenalan budaya Indonesia dan penelitian [7] memuat budaya Indonesia tersebut kedalam bentuk game edukasi. Penelitian ini lebih fokus pada konten ensiklopedia pakaian adat dunia dengan melengkapi fitur-fitur yang masih kurang dalam penelitian sebelumnya. Sehingga diharapkan hasil penelitian ini dapat menjadi sebuah aplikasi ensiklopedia digital yang mampu mengenalkan pakaian adat dari Indonesia maupun dunia. 


\section{PENELITIAN YANG TERKAIT}

Penelitian yang telah dilakukan terkait dengan dalam penelitian ini diantaranya berjudul aplikasi pengenalan pakaian adat tradisional indonesia berbasis android [5], artikel ini mempertegas bahwa pakaian adat sudah pernah diimplementasikan pada media android namun konten masih terbatas.

Penelitian [4] menjelaskan bahwa pakaian adat nusantara sudah diterapkan pada aplikasi game edukasi. Dari penelitianpenelitian yang sudah dilakukan sebelumnya, penelitian ini lebih berfokus pada konten ensiklopedia pakaian adat dunia yang disajikan dalam bentuk multimedia berbasis android.

\section{MULTIMEDIA \& ANDROID}

\section{A. Multimedia}

Dilihat dari kata multimedia yang terdiri dari kata multi dan media, berarti dapat diartikan sebagai gabungan dari beberapa media. Media dapat berupa teks, gambar, video, audio maupun animasi. Gabungan media tersebut kemudian dikemas menjadi satu kesatuan yang dimanipulasi secara digital dengan komputer sehingga menghasilkan produk informasi yang interaktif [8] [9].

\section{B. Rekayasa Produk Multimedia}

Rekayasa produk multimedia membahas tentang tahapantahapan dalam produksi perangkat lunak berbasis multimedia, mulai dari tahap awal persiapan sampai pemeliharaan sistem setelah selesai dibuat dan digunakan [10]. Ada beberapa metode yang dapat digunakan untuk membangun suatu produk multimedia, yaitu metode Vaughan, metode Luther, metode Luther-Sutopo, metode Villamil-Molina, dan metode Dastbaz. Pada penelitian ini menggunakan luther-sutopo.

\section{Android}

Android merupakan sistem operasi berbasis linux yang diterapkan dan dirancang untuk kebutuhan perangkat bergerak (mobile) dengan layar sentuh seperti smartphone dan tablet. Sistem operasi android resmi dirilis pada tahun 2007 [12] [13].

\section{METODE PENELITIAN}

Tahapan yang dilakukan pada penelitian ini dapat dilihat pada Gbr 1.

\section{A. Pengumpulan Data}

Pengumpulan data dilakukan dengan cara studi literatur dan komparasi dari berbagai jurnal sesuai topik penelitian yang dilakukan, melakukan observasi terhadap aplikasi-aplikasi ensikolpedia digital yang ada untuk melihat sejauh mana produk dibuat dan mencari peluang pengembangan aplikasi yang akan dibangun.

\section{B. Analisis Kebutuhan Sistem}

Tahap selanjutnya menganalisa dari data-data yang telah dikumpulkan, kemudian menentukan tentang apa yang harus dikerjakan oleh sistem serta karakter dan spesifikasi yang seperti apa yang harus dimiliki oleh sistem.

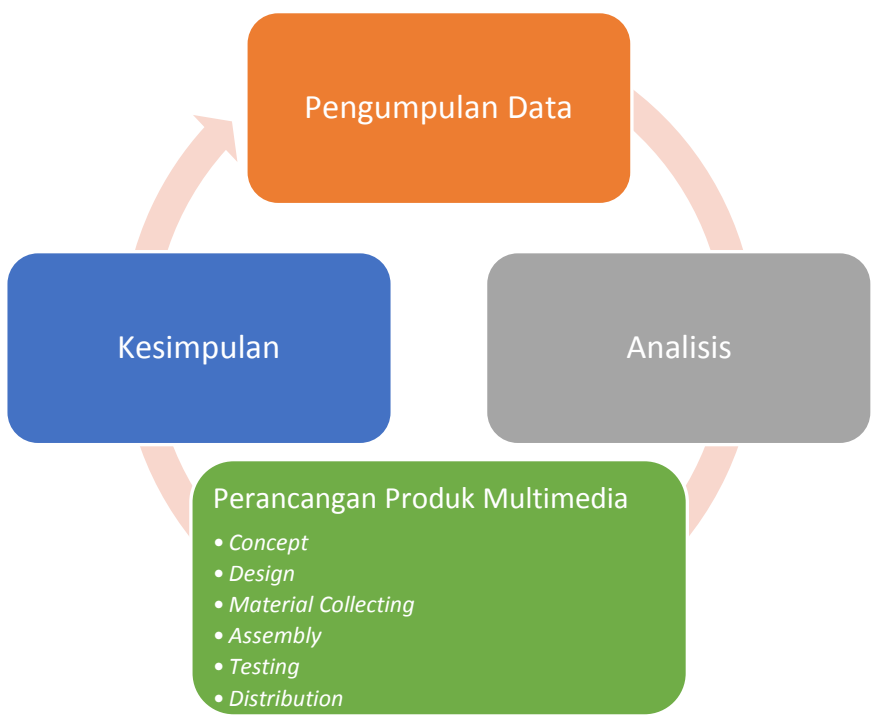

Gbr. 1 Metode Penelitian

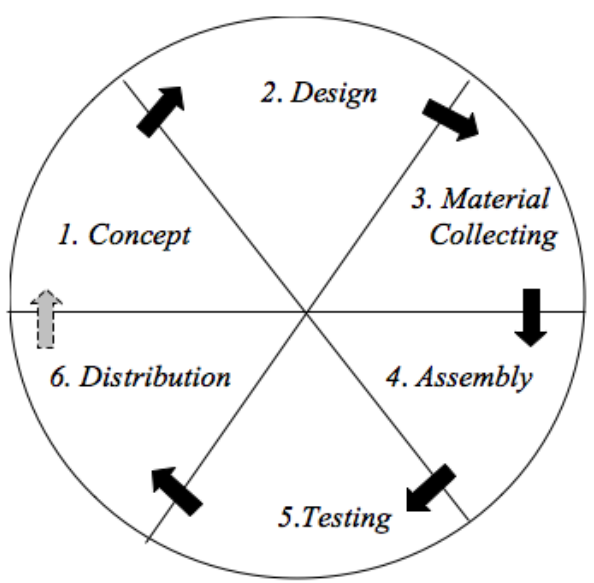

Gbr. 2 Metode rekayasa versi Luther [11]

\section{Perancangan Produk Multimedia}

Rekayasa perangkat lunak multimedia yang digunakan adalah versi Luther, dimana untuk membuat suatu produk multimedia dengan menggunakan metode ini harus melalui enam tahapan yang dilakukan secara berurutan dapat dilihat pada Gbr 2 .

Tahapan dari metode Luther adalah sebagai berikut [11]:

1) Concept: yaitu tahapan untuk menentukan tujuan, mengidentifikasi pengguna, jenis produk, dasar aturan, ukuran, dan target. Penentuan tujuan dan karakteristik pengguna dapat menentukan nuansa produk dan desain multimedia yang dikerjakan.

2) Design: pada tahapan ini harus dilakukan secara rinci yang dimulai pada gambaran awal produk seperti arsitektur aplikasi, antarmuka aplikasi, style serta elemen pendukung lainnya. Tahapan desain akan berpengaruh terhadap tahap selanjutnya yaitu material collecting dan assembly.

3) Material Collecting: melanjutkan tahap sebelumnya setelah desain kemudian mulai pengumpulan asset dan bahan sesuai kebutuhan produk multimedia yang akan dibangun. 
4) Assembly: yaitu tahapan penggabungan semua material kedalam proyek.

5) Testing: yaitu tahapan pengujian produk yang telah melalui tahapan assembly untuk melihat kemungkinan adanya kesalahan. Tahapan ini dapat dilakukan dengan metode alpha dan beta test.

6) Distribution: merupakan tahap terakhir dalam pembuatan produk multimedia, sebelum distribusi ke pengguna akhir produk dilakukan pengemasan produk dan semua asset yang dibangun pada suatu media bisa berupa CD, DVD maupun media online store.

\section{HASIL DAN PEMBAHASAN}

Pengumpulan data pada tahapan ini dilakukan dengan studi pustaka, dimulai dari pengumpulan informasi dan literatur penelitian sebelumnya, bahan-bahan dan buku yang mendukung penelitian ini.

\section{A. Analisis Kebutuhan Sistem}

Kebutuhan perangkat Mobile device untuk menjalankan aplikasi ensiklopedia pakaian adat, terdapat pada Tabel I.

TABEL I

SPESIFIKASI MINIMUM PERANGKAT MOBILE DEVICE

\begin{tabular}{|c|l|l|}
\hline No. & \multicolumn{1}{|c|}{$\begin{array}{c}\text { Nama } \\
\text { Komponen }\end{array}$} & \multicolumn{1}{c|}{ Spesifikasi Minimum } \\
\hline 1 & $\begin{array}{l}\text { Operating } \\
\text { System }(\text { OS })\end{array}$ & Android Jelly Bean versi 4.2 \\
\hline 2 & Processor & $\sim 1 \mathrm{GHz}$ \\
\hline 3 & Memory $(\mathrm{RAM})$ & $1 \mathrm{~Gb}$ \\
\hline 4 & Display & $480 \times 800 \mathrm{px}$ \\
\hline
\end{tabular}

TABEL II

KONSEP APLIKASI PAKAIAN ADAT DUNIA

\begin{tabular}{|l|l|}
\hline \multicolumn{1}{|c|}{ Nama } & \multicolumn{1}{c|}{ Deskripsi } \\
\hline Judul & Ensiklopedia Pakaian Adat \\
\hline Audiens & Publik \\
\hline Image & Image, format *.png \\
\hline Durasi & Unlimited \\
\hline Audio & Instrumen, format $*^{*}$ mp3 dan *.wav \\
\hline Animasi & Animasi 2D \\
\hline Interaktivitas & Tombol \\
\hline
\end{tabular}

\section{B. Implementasi Produk Multimedia}

1) Konsep (concept)

Hasil tahapan ini dapat dilihat pada Tabel II yang merupakan konsep dari aplikasi yang dibangun.

\section{2) Perancangan (Design)}

Perancangan desain yang telah dilakukan dapat dilihat pada Tabel III

\section{3) Pengumpulan Bahan (Material Collecting)}

Dalam pembuatan aplikasi ini bahan dikumpulkan dan ada yang dibuat sendiri menggunakan adobe photoshop CC, sedangkan untuk gambar materi-materi aplikasi di ambil dari internet dari situs freepik, jenis tulisan atau font DK Cover Up, animasi menggunakan feature motion tween dari adobe flash $\mathrm{CC}$, dan untuk (sound) suara yang digunakan dalam aplikasi ensiklopedia pakaian adat ini didapat dari berbagai media yang berformat *.mp3 yang kemudian dilakukan proses editing menggunakan Audacity.

TABEL III

Konsep PeRANCANGAN DESAIN SCENE

\begin{tabular}{|c|c|}
\hline Nama & Deskripsi \\
\hline Scene 1 & Scene Opening \\
\hline Scene 2 & Scene menu utama \\
\hline Scene 3 & $\begin{array}{l}\text { Scene Pakaian Adat Dunia, dimana scene } \\
\text { ini menampilkan list bendera } 20 \text { Negara. }\end{array}$ \\
\hline Scene 4 & $\begin{array}{l}\text { Merupakan scene Pakaian Adat Indoneisa } \\
\text { yang berisi peta pulau negara Indonesia } \\
\text { dimana pada peta tersebut terdapat tombol } \\
\text { untuk menuju scene pulau yang diinginkan. }\end{array}$ \\
\hline Scene 5 & $\begin{array}{l}\text { Merupakan scene Quiz dimana dalam quiz } \\
\text { ini user akan di uji daya pengetahuanya dan } \\
\text { ingatanya. }\end{array}$ \\
\hline Scene 6 & $\begin{array}{l}\text { Merupakan scene tentang aplikasi ini } \\
\text { merupakan informasi produk dan infomasi } \\
\text { pembuat produk. }\end{array}$ \\
\hline Scene 7 & $\begin{array}{l}\text { Merupakan scene provinsi Indonesia yang } \\
\text { berisi peta provinsi Indonesia yang telah } \\
\text { dipilih di scane } 4 \text {. Di dalam peta tersebut } \\
\text { terdapat tombol untuk menuju Scene } \\
\text { provinsi yang diinginkan. }\end{array}$ \\
\hline Scene 8 & $\begin{array}{l}\text { Merupakan scene gambar pakaian adat } \\
\text { berupa gambar vector. }\end{array}$ \\
\hline Scene 9 & $\begin{array}{l}\text { Merupakan scene informasi pakaian adat } \\
\text { yang menampilkan gambar, foto, logo, dan } \\
\text { deskripsi. }\end{array}$ \\
\hline
\end{tabular}

Gbr. 3 Menu Utama

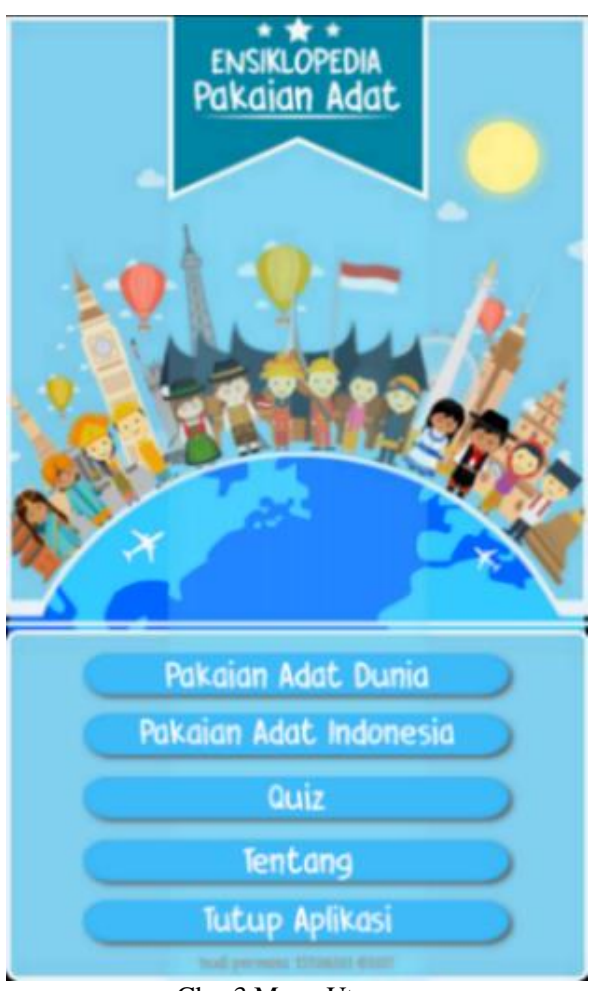




\section{4) Pemasangan (Assembly)}

Proses pemasangan menggunakan bahasa pemrograman ActionScript 3.0 yang merupakan bahasa pemrograman dalam Adobe Flash Professional CC. Hasil pada tahapan ini dapat dilihat mulai dari Gbr $3-5$.

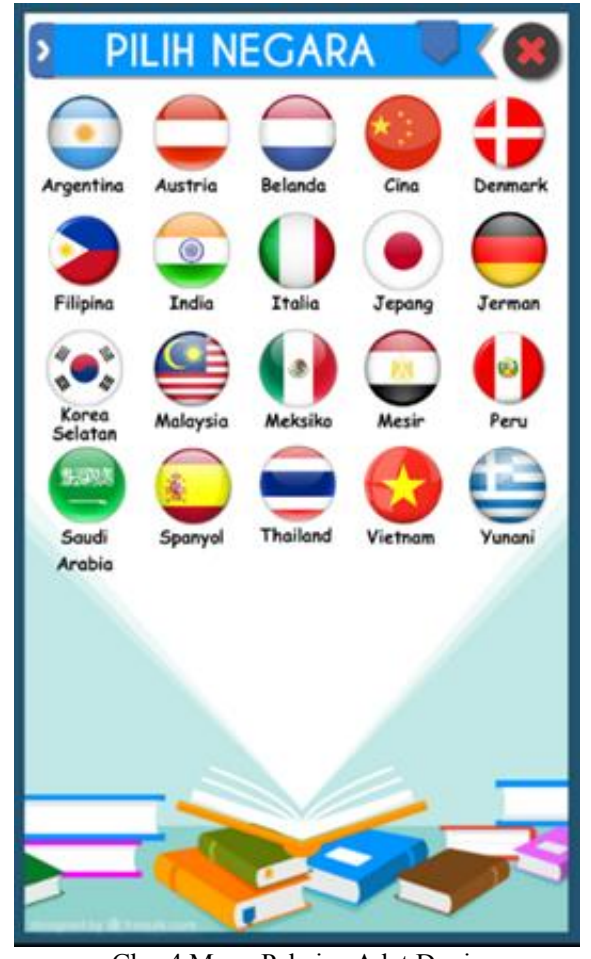

Gbr. 4 Menu Pakaian Adat Dunia

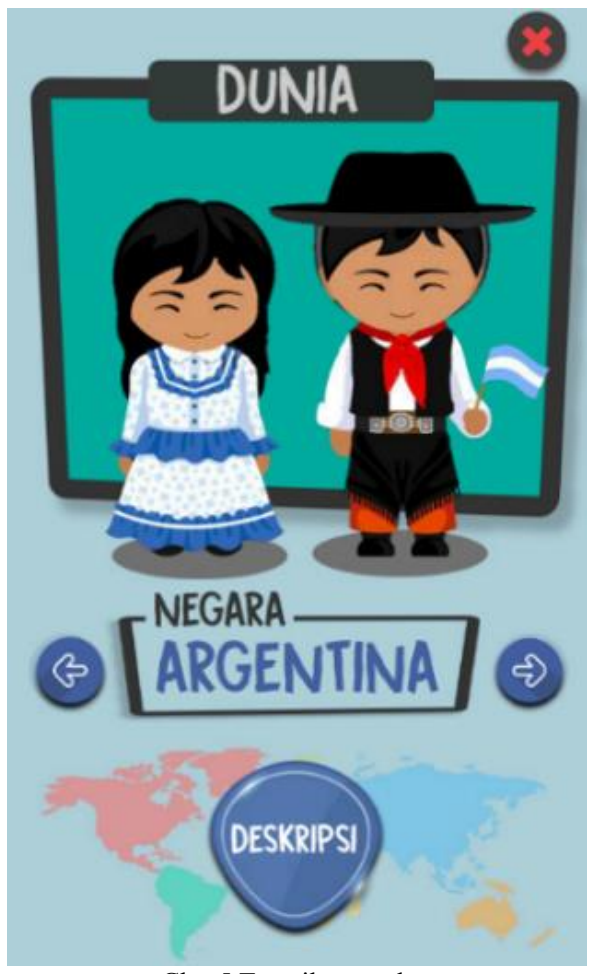

Gbr. 5 Tampilan gambar
Gbr. 3 merupakan tampilan aplikasi halaman utama yang berisi animasi serta pilihan menu yaitu pakaian adat dunia, pakaian adat Indonesia, quiz, tentang dan tutup aplikasi.

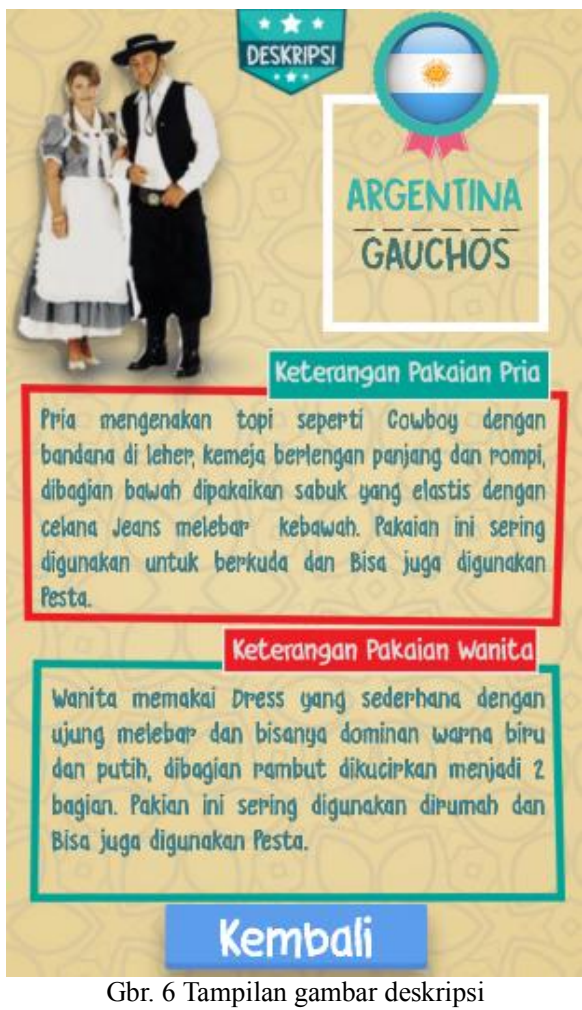

Sedangkan Gbr 4 adalah list negara dunia yang pada produk ensiklopedia digital mengenai pakaian adat ini berjumlah 20 negara. Sedangkan Gbr 5 merupakan tampilan hasil pemilihan dari setiap menu yang tampil pada Gbr 5 . Selanjutnya dari Gbr 5, pemilihan menu "Deskripsi" pada Gbr 5 akan menampilkan informasi seperti yang terlihat pada Gbr 6. Perpindahan dari setiap menu dari mulai menu utama dilakukan dengan navigasi Hirarki.

\section{5) Pengujian (Testing)}

Tahap pengujian pada penelitian ini menggunakan cara pengujian alpha dan beta test.

a) Pengujian Alpha Test: Tabel IV merupakan hasil pengujian Alpha dalam pembuatan perancangan aplikasi.

TABEL IV

HASIL PENGUJIAN ALPHA

\begin{tabular}{|l|l|l|}
\hline No. & Scene & Hasil Uji \\
\hline 1. & Scene 1 - Opening & Baik \\
\hline 2. & Scene 2 - Menu Utama & Baik \\
\hline 3. & $\begin{array}{r}\text { Scene 3 - Pakaian Adat Dunia } \\
\text { (20 Negara) }\end{array}$ & Baik \\
\hline 4. & $\begin{array}{r}\text { Scene 4 - Pakaian Adat Indonesia } \\
\text { (34 Provinsi) }\end{array}$ & Baik \\
\hline 5. & Scene 5 - Quiz & Baik \\
\hline 6. & Scene 6 - Tentang Aplikasi & Baik \\
\hline
\end{tabular}


TABEL V

KATEGORI TINGKAT VALIDITAS

\begin{tabular}{|c|c|}
\hline Presentase & Interpretasi \\
\hline $0-25$ & Tidak Baik \\
\hline $25-50$ & Kurang Baik \\
\hline $50-75$ & Baik \\
\hline $75-100$ & Sangat Baik \\
\hline
\end{tabular}

TABEL VI

HASIL PENGUJIAN KUESIONER SOAL NOMOR 1

\begin{tabular}{|c|l|c|c|}
\hline Jawaban & Keterangan & Responden & $\begin{array}{c}\text { Persentase } \\
(\mathbf{\%})\end{array}$ \\
\hline S & Setuju & 28 & 93,34 \\
\hline TT & Tidak Tahu & 1 & 3,33 \\
\hline TS & Tidak Setuju & 1 & 3,33 \\
\hline \multicolumn{2}{|c|}{ Jumlah } & 30 & 100 \\
\hline
\end{tabular}

b) Pengujian Beta Test: Pengujian Beta dilakukan oleh pengguna akhir produk dalam hal ini adalah pengguna (User), pemberian kuesioner kepada 30 responden setelah pengguna melihat dan mencoba aplikasi. Pada Tabel V merupakan kategori tingkat validitas untuk mengetahui kelayakan produk berdasarkan jumlah presentase.

Hal yang diujikan mulai dari bagian antarmuka (interface), cara pengoperasian, isi atau materi, manfaat dan pengembangan. Untuk mencari presentase masing-masing jawaban, data hasil kuesioner dihitung dengan rumus (1).

$$
Y=\frac{P}{Q} * 100 \%
$$

Dimana $\mathbf{P}$ adalah banyaknya jawaban responden tiap soal, $\mathbf{Q}$ adalah jumlah responden sedangkan $\mathbf{Y}$ merupakan nilai presentase. Salah satu contoh pertanyaan pada kuesioner yaitu "Menurut saya aspek visual seperti teks, gambar, animasi, background serta aspek audio (suara) sudah sesuai ?". Hasil pengujian kuesioner dapat dilihat pada Tabel VI.

Pertanyaan yang diberikan adalah 15 pertanyaan yang masing-masing jawaban pada setiap pertanyaan dihitung nilai presentasenya menggunakan rumus diatas. Setelah pengujian beta selesai dilakukan, maka didapat hasil kuesioner pada Tabel 7. Berdasarkan hasil yang diperoleh dari tabel hasil kuesioner pada tabel 7, didapat total jumlah persentase jawaban setelah dibagi dengan jumlah pertanyaan pada kuesioner yaitu $83 \%$.

\section{6) Distribusi (Distribution),}

Setelah program selesai dibangun dan telah melalui tahap pengujian, maka langkah selanjutnya adalah melakukan distribusi produk. Aplikasi ensiklopedia pakaian adat ini memiliki ukuran file mentah sebesar 65.2 MB dan ukuran file setelah menjadi *.apk adalah $10.8 \mathrm{MB}$, adapun alokasi memory RAM saat dijalankan pada perangkat android adalah 47 MB. Pendistribusian aplikasi dilakukan dengan cara unggah kedalam media internet seperti google drive ataupun langsung pada playstore.
TABEL VII

HASIL KUESIONER

\begin{tabular}{|c|c|}
\hline Pertanyaan & Persentase Jawaban (\%) \\
\hline 1 & 93,34 \\
\hline 2 & 96,37 \\
\hline 3 & 93,34 \\
\hline 4 & 100 \\
\hline 5 & 90 \\
\hline 6 & 90 \\
\hline 7 & 40 \\
\hline 8 & 100 \\
\hline 9 & 93,34 \\
\hline 10 & 100 \\
\hline 11 & 83,33 \\
\hline 12 & 86,67 \\
\hline 13 & 96.67 \\
\hline 14 & 6,67 \\
\hline 15 & 90 \\
\hline Jumlah & $1256 / 15=83,98$ \\
\hline
\end{tabular}

\section{KESIMPULAN}

Dari penelitian ini telah dibangun sebuah aplikasi ensiklopedia digital mengenai pakaian adat nasional dan dunia berbasis multimedia pada teknologi android sebagai media untuk memperoleh informasi mengenai pakaian adat dunia. Penerapan konsep multimedia dan penerapan media perangkat bergerak (android) dapat mempermudah proses distribusi dan transfer informasi yang interaktif, edukatif dan praktis sehingga pengguna bisa menggunakanya dimana pun dan kapapun. Hasil pengujian dengan nilai presentase sebesar 83\% serta hasil interpretasi "Sangat Baik" menunjukkan bahwa aplikasi ini layak digunakan. Metode Luther yang digunakan dalam rekayasa aplikasi multimedia ini dirasa cukup sesuai, dengan tahapan yang jelas dan runut sehingga dapat di ikuti sesuai dengan aktifitas rekayasa yang sebenarnya.

Saran yang dapat diberikan dari hasil penelitian ini adalah perlu penambahan konten dan informasi mengenai pakaian adat. Penambahan konten multimedia seperti Video dapat memberikan nilai lebih dari penyampaian informasi. Secara teknis aplikasi ensiklopedia digital ini dapat dikembangan kembali sehingga diharapkan mendukung disemua tipe layar perangkat mobile dan dapat digunakan disemua perangkat mobile dengan platform yang berbeda.

\section{DAFTAR PUSTAKA}

[1] “Operating System Market Share Worldwide," [Online]. Available: http://gs.statcounter.com/os-market-share. [Diakses 405 2018].

[2] H. Septian, E. W. Hidayat dan A. Rahmatulloh, "Aplikasi Pengenalan Bahasa Arab dan Inggris untuk Anak-Anak Berbasis Android," Jurnal Online Informatika, vol. 2, no. 2, pp. 71-78, 122017.

[3] A. Novandya, A. Kartika, A. Wibowo dan Y. Libriadiany, "Aplikasi Pengenalan Budaya Dari 33 Provinsi Di Indonesia Berbasis Android," ProSiding Seminar Ilmiah Nasional Komputer dan Sistem Intelijen (KOMMIT 2012), vol. 7, 2012.

[4] E. A. Pangestika, Aripin dan D. W. Setyanto, "Perancangan Game Edukasi Pengenalan Pakaian Adat Nusantara," Udinus Repository, 2015. 
[5] I. Fitri, "Ensiklopedia Pakaian Adat Tradisional Indonesia Berbasis Android," vol. Tidak diterbitkan, no. Universitas Bina Darma, p. Skripsi, 2016.

[6] F. Adnan, Aplikasi Pengenalan Budaya Indonesia berbasis Android, vol. Tidak diterbitkan, no. Universitas Gunadarma, p. Jurnal Penelitian, 2012.

[7] I. R. D. Renavitasari, D. A. Irawati dan A. Prasetyo, "Pengembangan Game Edukasi Pengenalan Budaya Indonesia "Jelajah" Berbasis Android," Seminar Informatika Aplikatif Polinema, vol. 1, 2016.

[8] B. S. D. Oetomo, E-education. Konsep Teknologi dan Aplikasi Internet Pendidikan, Yogyakarta: Andi, 2002.
[9] T. Vaughan, Multimedia: Making it Work Sixth Edition, New York : McGraw-Hill Companies. Inc, 2004

[10] I. Sommerville, Software Engineering. 9th Edition., America: Pearson Education .Inc, 2011

[11] T. Arifianto, Membuat Interface Aplikasi Android Lebih Keren dengan LWIT, Yogyakarta: Andi., 2011.

[12] S. Hermawan S, Mudah Membuat Aplikasi Android, Yogyakarta: Andi Offset, 2011.

[13] I. Binanto, Multimedia Digital Dasar Teori dan Pengembangannya, Yogyakarta: Andi , 2010 